\title{
Morphological and Molecular Characterization of Several Actinophages Isolated from Soil Which Lyse Streptomyces cattleya or S. venezuelae
}

\author{
By J. ANNÉ, 1 + W. WOHLLEBEN, ' H. J. BURKARDT, 2 R. SPRINGER ? \\ AND A. PÜHLER' \\ 'Department of Genetics, University of Bielefeld, Postfach 8640, D-4800 Bielefeld, FRG \\ 'Department of Microbiology, Unitersity' of Erlangen, D-8520 Erlangen, FRG
}

(Receiced 9 February 1984)

\begin{abstract}
Several lytic and lysogenic actinophages were isolated from soil samples infected with Streptomyces cattleya and $S$. venezuelae. The morphologies and some biological properties of the phages, and the physico-chemical characteristics of their DNAs, were compared. Electron micrographs indicated that all the phage heads were of an icosahedral form, but head size and length of the tail varied. Two of the phages had a broad host range; the other isolates could lyse only a limited number of species. The molecular sizes of the phage DNAs were between $32 \cdot 2$ and $98.5 \mathrm{~kb}$ as estimated by electron microscopy and restriction enzyme analysis. The same study also indicated that one of the DNA species contained cohesive ends. The $G+C$ content of the DNAs ranged between 45.1 and $74.2 \mathrm{~mol} \%$ as estimated from melting studies. Sedimentation velocity experiments implied that several of the phage DNAs were probably heavily glycosylated or methylated. These modifications might explain the partial or slow digestion of some of the DNAs by several of the 23 restriction enzymes tested. Protoplasts of the appropriate Streptomyces strains could be efficiently transfected with phage DNA in the presence of $25 \%$ (w/v) polyethylene glycol (mol. wt 6000).
\end{abstract}

\section{INTRODUCTION}

Actinophages have been isolated and investigated for a variety of reasons, including: for the problems they cause in the fermentation industry, as taxonomic tools for typing of streptomycetes (Bradley et al., 1961) and in genetic studies (Lomovskaya et al., 1980). The progress in the development of phage vectors has resulted in actinophages becoming of increasing interest in recombinant DNA technology (Chater, 1980; Chater et al., 1982; Lomovskaya et al., 1982).

The usefulness of a bacteriophage as a vector in recombinant DNA technology depends on its DNA and the phage host range. Ideally, the phage should have a wide host range, a genome which can be deleted for some non-essential regions, and target sites for several common restriction enzymes. It must also be possible to transfect the phage DNA or its recombinant molecules. With these ideas in mind we have screened several soil samples for actinophages which could lyse strains of the industrially-important Streptomyces cattleya or $S$. venezuelae and we have performed a morphological and molecular characterization of the isolates obtained. In addition, the possibility of transfection was tested using polyethylene glycol (PEG) (Suarez \& Chater, 1980; Isogai et al., 1980).

\section{METHODS}

Organisms. Phages from soil samples were isolated using Streptomyces cattleya NRRL 8057 and S. venezuelae ETH 14630 as indicator strains. The host range of the different phages isolated was checked for the following

† Present address: University of Leuven, Rega Institute, Minderbroedersstraat 10, B-3000 Leuven, Belgium. 
Streptomyces strains: $S$. ghanaensis Hoechst 5/1;S. ederensis ATCC 15304; S. geysiriensis ATCC $15303 ; S$. bambergiensis; $S$. coelicolor M130 (John Innes Institute, Norwich Collection); S. lividans 1326 (John Innes Institute, Norwich Collection); S. clavuligerus NRRL 3585; Streptomyces Y5633 (FH 1426); S. glaucescens (ETH 566); S. tendae; S. aureofaciens; S. lipmanii ATCC 27357; S. olivaceus ATCC $21379 ; S$. griseus; S. diastaticus NRRL 2650; $S$. antibioticus ATCC 8663; $S$. aurantiogriseus ATCC 27435; S. pristinaespiralis CBS 914.69;S rimosus CBS 938.68; $S$. loidensis A TCC 11415; $S$. erythreus; $S$. mumidans $R 760 ; S$ griseosporeus ATCC $27435 ; S$. osteogriseus NRRL 2558; S. virginiae; S. graminofaciens ATCC 12705.

Media and buffers. Streptomyces strains were cultivated on Penassay medium (Antibiotic medium III, Oxoid) or RGMC which contained $\left(\mathrm{g} \mathrm{I}^{-1}\right)$ : tryptone, 10 ; yeast extract, $1 ; \mathrm{NaCl}, 8 ;$ glucose, $1 ; \mathrm{MgCl}_{2}, 1 ; \mathrm{CaCl}_{2} .2 \mathrm{H}_{2} \mathrm{O}, 0 \cdot 3$. For phage propagation the strains were grown on phage medium (Korn et al., 1978). Phages were collected, stored or diluted in phage buffer, i.e. $\left(\mathrm{g}^{-1}\right)$ : bactopeptone, $1.0 ; \mathrm{CaCl}_{2} .2 \mathrm{H}_{2} \mathrm{O}, 0.74 ; \mathrm{pH} 7 \cdot 2$. Phage DNA was stored in TE-buffer composed of $1 \mathrm{mM}$-EDTA and $10 \mathrm{~mm}$-Tris, pH 7.5. For protoplast production Streptomyces mycelium was grown in medium $S$ (Okanishi et al., 1974) supplemented with $1 \%$ glycine. Protoplasts were stabilized in medium P and regeneration was on R2YE-medium (Chater et al., 1982).

Isolation of Streptomyces phages. To detect the possible presence of phages in soil samples, $100-200 \mathrm{~g}$ samples were incubated for one week in phage medium containing mycelial fragments $\left(10^{7} \mathrm{c.f} . \mathrm{u}^{\mathrm{m}} \mathrm{ml}^{-1}\right)$ of the indicator strain, i.e. S. venezuelae or S. cattleya, either at room temperature (with shaking at intervals) or at $30^{\circ} \mathrm{C}$ (with shaking at 120 r.p.m.). After incubation, the samples were centrifuged $(5 \mathrm{~min}, 3000 \mathrm{~g}$ ) and then either sterilized by membrane filtration, or treated with a few drops of chloroform to kill all viable cells.

The supernatant solutions were investigated for the presence of Streptomyces phages using the soft agar overlay method. A $1 \mathrm{ml}$ sample of a homogenized overnight culture of a susceptible strain ( $10^{7}$ c.f.u. $\mathrm{ml}^{-1}$ ) grown in liquid phage medium was mixed with $0.1 \mathrm{ml}$ of the supernatant solution to be investigated and $2 \mathrm{ml}$ of soft phage medium agar (at $45^{\circ} \mathrm{C}$ ). This suspension was subsequently poured onto plates of phage medium. The homogenized mycelium suspension could be stored at $4^{\circ} \mathrm{C}$ for at least one week.

Phages were detected by the appearance of plaques in the bacterial lawn after overnight incubation at $30^{\circ} \mathrm{C}$. Distinct phages could be distinguished by differences in plaque morphology, size and turbidity. To purify different phage types, serial replating from single plaques was carried out.

One phage (P23) used in the experiments was obtained from Dr F. Korn. Technische Hochschule, Darmstadt, FRG.

Preparation of high titre /ysates. To obtain phage suspensions of high titres, confluent plate lysates were prepared by plating $10^{4}-10^{5}$ p.f.u. per plate and incubating overnight. Phages from these plates were collected by addition of $5 \mathrm{ml}$ phage buffer and soaking at room temperature for $30 \mathrm{~min}$. Shaking-flask lysates were prepared by the addition of $10^{5}$ p.f.u. to $200 \mathrm{ml}$ cultures containing homogenized mycelium $\left(10^{7}\right.$ c.f.u. $\left.\mathrm{ml}^{-1}\right)$. Incubation was carried out at $30^{\circ} \mathrm{C}$ and 120 r.p.m. for $40 \mathrm{~h}$. Bacteria were removed by centrifugation $(10 \mathrm{~min}, 4000 \mathrm{~g})$. Phage preparations were sterilized by treatment with chloroform.

Purification of phages and isolation of phage DNA. Phage particles were concentrated by centrifugation at $150000_{g}$ for $1 \mathrm{~h}$. Phage pellets were resuspended in a minimal volume of phage- or TE-buffer, and treated with a small amount $\left(10 \mu \mathrm{g} \mathrm{ml} l^{-1}\right)$ of DNAase and RNAase $\left(1 \mathrm{~h}, 37^{\circ} \mathrm{C}\right)$. Purification was achieved by $\mathrm{CsCl} \mathrm{gradient}$ centrifugation ( $5.5 \mathrm{~g} \mathrm{CsCl}$ in $7 \mathrm{ml} \mathrm{TE}$-buffer) at $100000 \mathrm{~g}$ for $20-24 \mathrm{~h}$. After collecting the phage band, which was grey-white in colour, $\mathrm{CsCl}$ was removed by dialysis against $\mathrm{TE}$-buffer.

DNA was extracted using phenol saturated with $0.1 \mathrm{M}$-Tris/HCl buffer, pH 8.0. After gentle mixing and centrifugation in an Eppendorf centrifuge for $3 \mathrm{~min}$, the aqueous phase containing phage DNA was removed and dialysed against TE-buffer.

Identification of temperate phages. Temperate phages could be distinguished from non-temperate phages by the appearance of lysogenic strains in the centre of the plaques. These lysogenic bacteria were immune to superinfection by the same phage. Furthermore, in a culture of a lysogenic strain, free phage particles would be detected, since lysogenic strains would spontaneously go into the lytic cycle at a low level. This transition to the lytic cycle could be increased by exposure to UV light ( $260 \mathrm{~nm}$; germicidal lamp, Sylvania G8T5, USA).

Host range. Host range was determined using a qualitative spot test $\left(0.1 \mathrm{ml}\right.$ phage suspension of $10^{10}$ p.f.u.) on lawns of different strains. If plaques appeared the strain was considered to be susceptible to the particular phage.

Protoplast formation and transfection. Mycelial fragments grown for $20 \mathrm{~h}$ in medium $\mathrm{S}$ containing $1^{\circ} \%$ glycine were treated with lysozyme (10 $\mathrm{mg} \mathrm{ml}^{-1}$ ) in medium P for $15-45$ min to induce protoplast production (Okanishi $e t$ al., 1974). Protoplasts were separated from mycelial debris by low speed centrifugation $(700 \mathrm{~g}, 5 \mathrm{~min})$ and they were subsequently washed in medium $P$ to remove lysozyme.

To transfect frotoplasts, 5-10 $\mu \mathrm{g}$ phage DNA was added to about $10^{8}$ pelleted protoplasts followed by the addition of $0.5 \mathrm{ml}$ of a solution of $25 \%(\mathrm{w} / \mathrm{v})$ PEG, mol. wt 6000 , in $0.01 \mathrm{M}-\mathrm{CaCl}_{2}$ at pH 8.0 , with $0.05 \mathrm{M}$ glycine $/ \mathrm{NaOH}$. After I min, $0.5 \mathrm{ml}$ medium $\mathrm{P}$ was added, and the protoplasts were centrifuged and washed once more with $1 \mathrm{ml}$ medium $P$. Transfection was observed by plaque formation in the lawn of bacteria regenerated from protoplasts on R2YE-medium.

Determination of $G+C$ content of $D N A$. This was estimated both by buoyant density $(\theta)$ determination and by 
determination of the thermal denaturation temperature $\left(T_{m}\right)$. Buoyant density measurements were carried out according to Pühler et al. (1979); $T_{m}$ values were estimated in $0.015 \mathrm{M}-\mathrm{NaCl}$ and $1.5 \mathrm{mM}$-sodium citrate (Marmur \& Doty, 1962) using a double beam Beckman UV 5230 spectrophotometer at $260 \mathrm{~nm}$ with a thermocouple in the sample cuvette for temperature reading. The molar percentage base composition can be derived from sedimentation velocity studies using the formula $G+C=10 \cdot 12 \theta-16 \cdot 74$ (Woodward \& Lebowitz, 1980) and from thermal denaturation studies according to the equation $G+C=\left(T_{m}-49.9\right) / 0.48$ (Mandel \& Marmur. 1968).

Electron microscopy of phages and phage DNA. Phage particles were examined after negative staining (Valentine ef al., 1968). For phage DNA the methods of Burkardt et al. (1978) were used.

Isolation of extrachromosomal DNA of Streptomyces spp. Mycelium of Streptomyces spp. cultivated in $50 \mathrm{ml}$ medium $S$ for $48 \mathrm{~h}$ was harvested by centrifugation $(10 \mathrm{~min}, 26000 \mathrm{~g})$. homogenized and washed twice in TEbuffer containing $10 \%(\mathrm{w} / \mathrm{v})$ sucrose. As described by Wohlleben \& Pühler (1982), washed mycelium was resuspended in $5 \mathrm{ml} \mathrm{LI}$ (containing $50 \mathrm{~mm}$-glucose, $10 \mathrm{~mm}$-CDTA, $25 \mathrm{~mm}$-Tris, pH 8.0) supplemented with $10 \mathrm{mg}$ lysozyme $\mathrm{ml}^{-1}$, and the suspension was incubated for $30 \mathrm{~min}$ at $30^{\circ} \mathrm{C}$. Following protoplast formation $10 \mathrm{ml}$ of an alkaline SDS solution ( $1 \% \mathrm{SDS}$ in $0.2 \mathrm{M}-\mathrm{NaOH}$ ) was added and gently mixed. This suspension was kept on ice for $5 \mathrm{~min}$. After addition of $7.5 \mathrm{ml} 3 \mathrm{M}$-potassium acetate, $\mathrm{pH} 4.8$, the lysate was left on ice for a further $60 \mathrm{~min}$. Proleins and chromosomal DNA were removed by centrifugation $(25000 \mathrm{~g}, 15 \mathrm{~min}$ ) and plasmid DNA was precipitated by the addition of $0.6 \mathrm{vol}$. 2-propanol. After $30 \mathrm{~min}$ at room temperature, the DNA was collected by centrifugation $(25000 \mathrm{~g}, 15 \mathrm{~min})$ and dried at $60^{\circ} \mathrm{C}$ for $10 \mathrm{~min}$. The DNA was further purified by buoyant density gradient centrifugation in $\mathrm{CsCl}(7 \mathrm{~g}$ in $7 \mathrm{ml})$ containing ethidium bromide $\left(8.5 \mathrm{mg} \mathrm{ml}^{-1}\right)$. After centrifugation $(85000 \mathrm{~g}, 45 \mathrm{~h})$ the DNA band was visualized under UV light $(300 \mathrm{~nm})$, and was removed using a syringe. The ethidium bromide was extracted by isoamyl alcohol saturated with $\mathrm{NaCl}$ : $\mathrm{CsCl}$ was removed by dialysis against TE-buffer.

Restriction enzyme analy'sis of phage DNA. Phage DNA was incubated with 23 different restriction enzymes, using the assay conditions described by the manufacturers. Results of digestion were determined by agarose gel electrophoresis ( $1 \%$ agarose in Tris/acetate buffer, pH 7.8: $40 \mathrm{~mm}$-Tris, $10 \mathrm{~mm}$-sodium acetate, 1 mM-EDTA). Electrophoresis was carried out at $8 \mathrm{~V} \mathrm{~cm}{ }^{\prime}$ for $2.5 \mathrm{~h}$. After staining with ethidium bromide. DNA bands were visualized on a UV transilluminator at $300 \mathrm{~nm}$ and photographed on Polaroid film.

The presence of cohesive ends was investigated by electron microscopic analysis (open circular molecules which are formed spontaneously during the droplet preparation indicate complementary single-stranded ends) as well as by comparison of staining intensities of different fragments of restricted DNA in samples subjected to heating $\left(70^{\circ} \mathrm{C}\right)$ and rapid cooling with fragments not treated in this way. When cohesive ends are present, non-heated samples contain more fused sticky ends: heated (followed by rapid cooling) samples display more unfused cohesive ends. In addition. the sum of the lengths of unfused sticky ends should be equal to the length of the fragment containing fused cohesive ends.

Fragment sizes were determined by comparison of the electrophoretic mobility of the fragments with that of coliphage $\lambda$ c1857S7 (Miller, 1972) fragments obtained after digestion with EcoRI, HindIII and the combined digestion EcoRI + HindIII.

\section{RESULTS AND DISCUSSION}

\section{Isolation and morphological characterization of phages}

Phage particles were detected in four out of the six soil samples tested. No real differences were observed in isolation efficiency between shaking cultures at $30^{\circ} \mathrm{C}$ or standing cultures at room temperature. Using differences in plaque morphology and lysogeny as criteria, nine phage types could be isolated (Table 1). High phage titres, i.e. $10^{10}-10^{12}$ p.f.u. $\mathrm{ml}^{-1}$, were obtained from confluent plate lysates.

Electron microscopic investigations of the different phages showed that all the phage heads were of an icosahedral form, but phage head size and tail length varied considerably (Table 1). Some of the phages (e.g. CPC) had a very long tail (Fig. I b). Another type (CRK) had a very short tail and, in contrast to most of the other phages, showed no base plate (Fig. $1 a$ ). The extremely short tail of CRK might explain the formation of rather stable conglomerates giving rise to three separate phage bands after $\mathrm{CsCl}$ gradient centrifugation.

\section{Host range}

The host ranges of the different phages were examined by plaque formation on 27 different strains. All the phages except P23 and CPC had a relatively narrow host range; VWB could lyse 

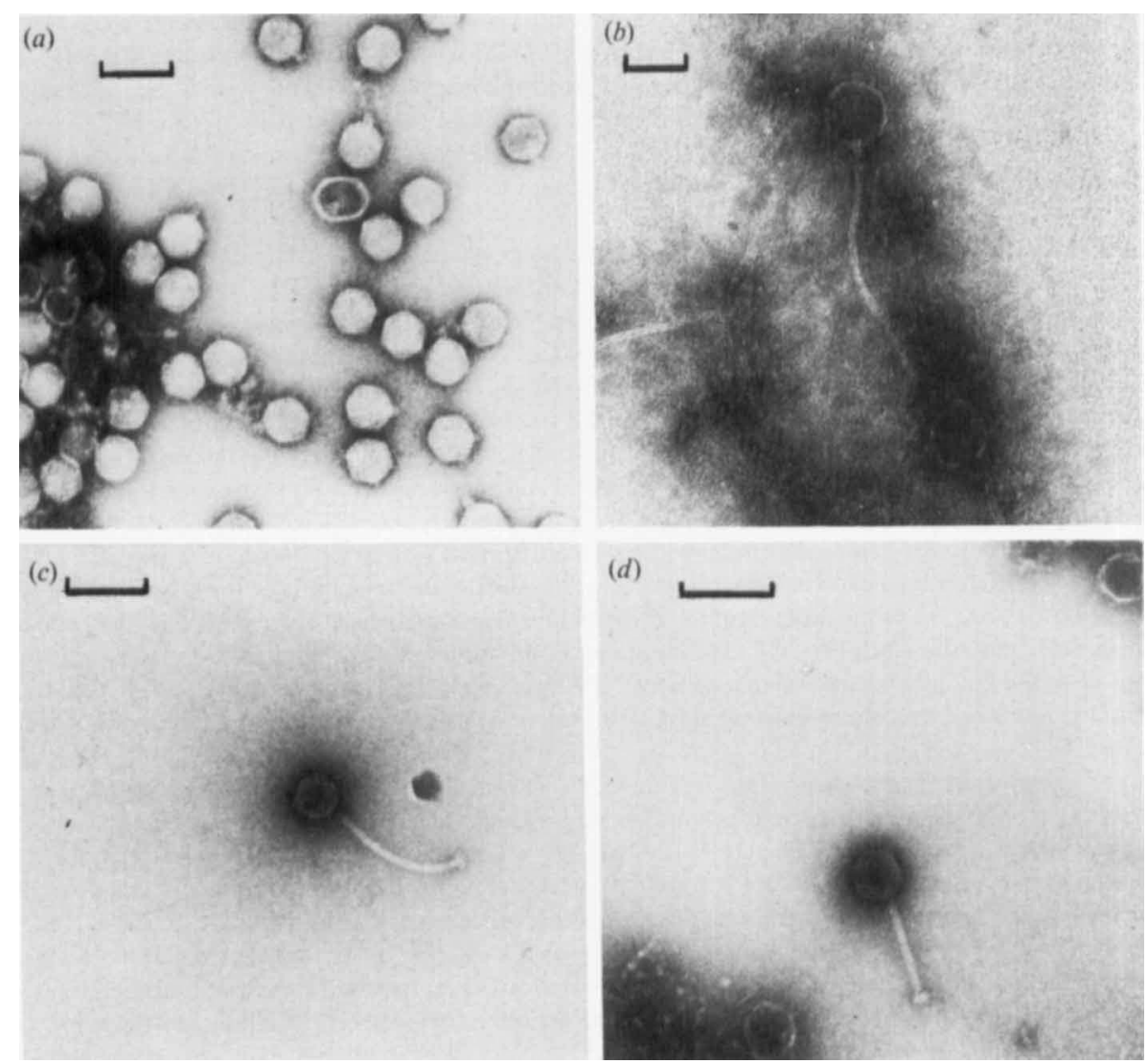

Fig. 1. Electron micrographs of different Streptomyces phages (a) CRK, (b) CPC, (c) VWB, (d) CTK. The bar markers represent $0.1 \mu \mathrm{m}$.

Table 1. Morphological characteristics of different Streptomyces phages

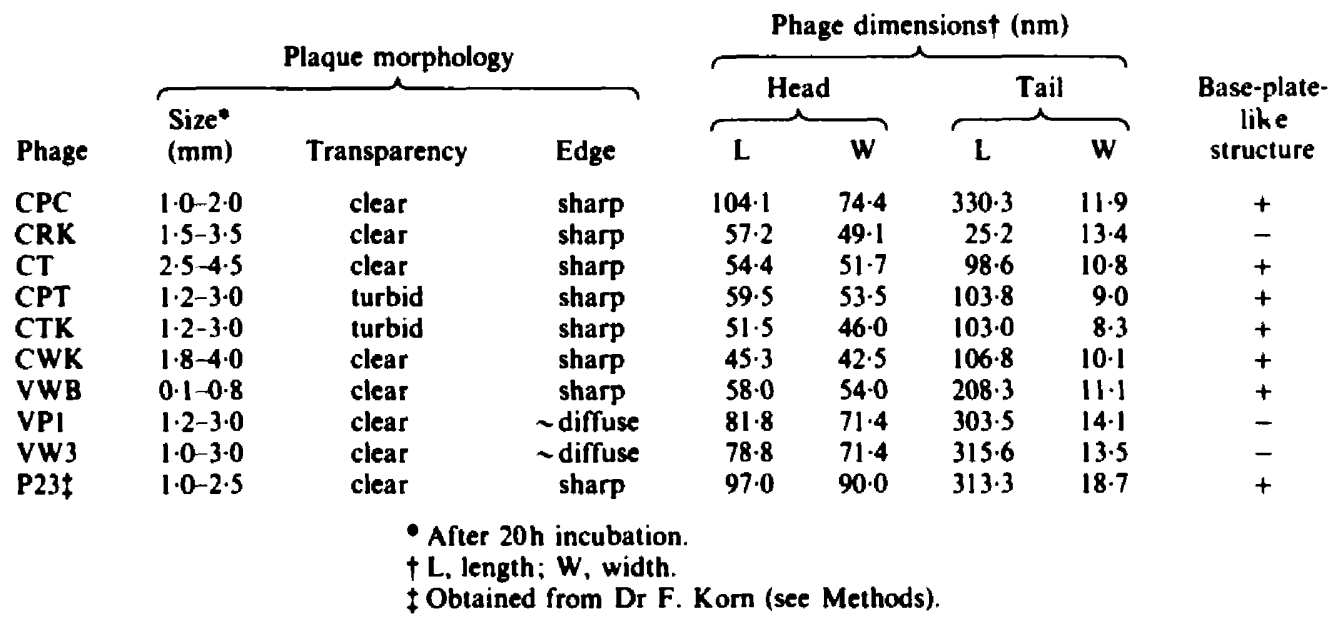

only one strain of the species tested (Table 2). The species $S$. olivaceus, $S$. lipmanii, S. erythreus and $S$. clavuligerus were most susceptible to the different phages isolated. 


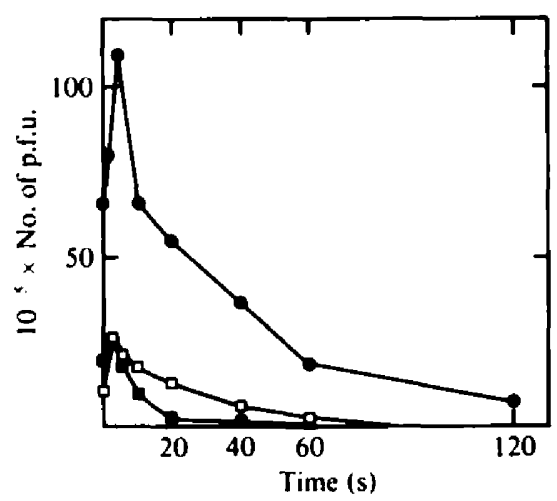

Fig. 2. Influence of UV irradiation $(260 \mathrm{~nm})$ on the release of phages from lysogenic strains. Lysogenic bacteria were grown for $24 \mathrm{~h}$ in phage medium and collected by centrifugation. After washing. respectively $0.5 \times 10^{7}, 2.0 \times 10^{7}$ and $1.0 \times 10^{7} \mathrm{c.f}$.u. $\mathrm{ml}^{-1}$ of $S$. venezuelae VWB ( $\square$ ). S. cattleya CT $(\square)$ and $S$. cattleya CPT (O) were irradiated and the suspensions were tested for the presence of free phages.

Table 2. Physical characteristics of Streptomyces phages and their host range

\begin{tabular}{|c|c|c|c|}
\hline \multirow[b]{2}{*}{ Phage } & \multicolumn{2}{|c|}{ Size (kb) } & \multirow[b]{2}{*}{ Host range } \\
\hline & $\begin{array}{l}\text { From restriction } \\
\text { enzyme analysis }\end{array}$ & $\begin{array}{c}\text { From EM } \\
\text { measurements }\end{array}$ & \\
\hline \multicolumn{4}{|l|}{ Virulent } \\
\hline $\mathbf{P} 23$ & $98.5 \pm 14$ & ND & $\begin{array}{l}\text { S. venezuelae, } S . \text { cattleya, } S \text {. ghanaensis, } S \text {. olivaceus, } \\
\text { S. claruligerus, S. ederensis, S. geysiriensis, } \\
\text { S. bambergiensis, S. coelicolor, S. lividans, } \\
\text { Streptomyces Hoechst 5633, S. glaucescens, S. tendae, } \\
\text { S. aureofaciens, S. lipmanii, S. griseus, S. antibioticus, } \\
\text { S. rimosus, S. loidensis, S. erythreus, S. numidans, } \\
\text { S. griseosporeus, S. graminofaciens }\end{array}$ \\
\hline $\begin{array}{l}\text { VPI }(=V W 3) \\
C P C\end{array}$ & $95.4 \pm 11$ & $\begin{array}{c}95 \cdot 84 \pm 4.85 \\
74 \cdot 19\end{array}$ & $\begin{array}{l}\text { S. tenezuelae, } S \text {. olivaceus, } S \text {. clavuligerus, } S \text {. lipmanii } \\
S \text {. cattleya, } S \text {. ghanaensis, } S \text {. olivaceus, } S \text {. clavuligerus, } \\
\text { S. ederensis, S. geysiriensis, } S \text {. bambergiensis, } \\
\text { Streptomyces Hoechst } S 633, S \text {. glaucescens. } \\
S . \text { griseus, } S \text {. rimosus, S. erythreus }\end{array}$ \\
\hline CRK & $38 \cdot 5 \pm 2$ & $32.2 \pm 0.7$ & $S$. cartleya, $S$. olivaceus, $S$. griseus \\
\hline CWK & $38 \cdot 3 \pm 2$ & $37.87 \pm 1.3$ & $\begin{array}{l}\text { S. cattleya, } S \text {. olivaceus, } S \text {. clavuligerus, } S \text {. lipmanii, } \\
\text { S. antibioticus, } S \text {. erythreus, } S . \text { griseosporeus }\end{array}$ \\
\hline \multicolumn{4}{|l|}{ Temperate } \\
\hline VWB & $46.0 \pm 3.9$ & $41.94 \pm 0.95$ & S. venezuelae \\
\hline CT & $52.5 \pm 1.2$ & $39.59 \pm 1.39$ & $\begin{array}{l}\text { S. cattleya, } S \text {. olivaceus, } S \text {. clavuligerus, } S \text {. lipmanii, } \\
\text { S. antibioticus, } S . \text { aurantiogriseus, } S \text {. erythreus, } \\
\text { S. griseosporeus }\end{array}$ \\
\hline CPT $(=$ CTK $)$ & $40.2 \pm 0.5$ & 40 & S. cattleya, $S$. ghanaensis, $S$. olivaceus, $S$. clavuligerus \\
\hline
\end{tabular}
ND, Not done: - could not be estimated.

\section{Isolation and properties of lysogenic strains}

As indicated in Methods, temperate phages could be recognized by the development of lysogenic bacteria at the centre of the plaques. Four of the ten different phages investigated were identified as temperate, viz. CPT, CTK, CT and VWB. Lysogenic strains of S. cattleya containing CPT, CT or CTK were immune to superinfection by CPT, CT or CTK and also by $C W K$, but they were still susceptible to CPC or P23. Strains of $S$. venezuelae containing temperate VWB were susceptible to P23, and also to VP1 and VW3.

Spontaneous transition from the temperate stage to the lytic cycle occurred at a rate of $1-5 \%$ of the number of viable cells. Induction of the lytic cycle could be enhanced by exposure (1-5s) of the lysogenic strain to UV $(260 \mathrm{~nm})$. Longer irradiation decreased the number of viable phages (Fig. 2). 
Preliminary experiments to investigate whether the prophages were integrated in the chromosome or existed as an extrachromosomal element (as for $\mathbf{P l}$ phage of $S$. fradiae phage SF 1 : Chung, 1982) indicated that they were probably integrated in the chromosome, because no extrachromosomal DNA could be observed. For the detection of extrachromosomal DNA, $48 \mathrm{~h}$ old mycelium of a lysogenic Streptomyces species grown in medium S was lysed and DNA was extracted according to the method of Wohlleben \& Pühler (1982). This method has been proven to be efficient for the isolation of plasmid-like DNA in streptomycetes. In the case of temperate phages (CT, CPT or CWK), no extrachromosomal DNA was observed after CsCl centrifugation. For the VWB lysogenic $S$. venezuelae strain, which also contained the plasmid $\mathrm{pSVH}_{1}(12.6 \mathrm{~kb})$ (W. Wohlleben \& A. Pühler, unpublished observations), only the latter plasmid but no other extrachromosomal DNA band was observed. These results proved the utility of this procedure for the isolation of plasmid DNA. However, if the prophages were present as a low copy number plasmid or as linear plasmids (Hirochika \& Sakaguchi, 1982), this method might be unsatisfactory.

\section{Influence of $\mathrm{Ca}^{2+}$ and $\mathrm{Mg}^{2+}$ on plating efficiency of phages CPT, CRK and $\mathrm{VWB}$}

The efficiency of plaque formation of phage particles was dependent on the $\mathrm{Ca}^{2+}$ and $\mathrm{Mg}^{2+}$ concentrations in the medium for the three phages studied: CPT and CRK on $S$. cattleya and VWB on $S$, venezuelae.

On phage medium agar containing increasing concentrations of $\mathrm{Ca}^{2+}$ and/or $\mathrm{Mg}^{2+}$ (as $\mathrm{MgSO}_{4} .7 \mathrm{H}_{2} \mathrm{O}$ ), the optimum concentration of $\mathrm{Ca}^{2+}$ was different for different phages (Table 3). $\mathrm{Mg}^{2+}$ was not required for plaque formation when the medium contained $\mathrm{Ca}^{2+}$. It could only partially replace $\mathrm{Ca}^{2+}$ in the case of VWB or CRK. In combination with $\mathrm{Ca}^{2+}$ there was no effect of $\mathrm{Mg}^{2+}$ on the plating efficiency for the different phages investigated.

From these results, it was concluded that the $\mathrm{Ca}^{2+}$ requirement for plaque formation varied for different phages and that, in fact, the $\mathrm{Ca}^{2+}$ concentrations in the phage medium had to be adjusted for each type of phage.

\section{Protoplast formation and transfection}

For many Streptomyces spp., protoplast formation can be induced by the action of lysozyme, when mycelium is grown in a medium containing glycine (Okanishi et al., 1974). For $S$. cattleya and $S$. venezuelae, lysozyme was also effective for protoplast formation. After 15-30 min incubation in medium $P$ containing $10 \mathrm{mg}$ lysozyme $\mathrm{ml}^{-1}$ the mycelia were almost entirely converted to protoplasts. Regeneration of protoplasts occurred effectively on R2YE-medium. The number of osmotically stable cells in the protoplast preparation was investigated by osmotic shock treatment in distilled water. For $S$. cattleya protoplast preparations, the number of osmotically stable cells was, on average, less than $1 \times 10^{-3} \%$ of the total number of viable cells, i.e. about $10^{9}$ c.f.u., and for $S$. venezuelae this number was less than $1 \times 10^{-1} \%$.

Efficient transfection of Streptomyces protoplasts is possible by treatment of the protoplasts with PEG in the presence of phage DNA (Suarez \& Chater, 1980; Isogai et al., 1980). Transfection could be observed by plaque formation in the regeneration plates after $48 \mathrm{~h}$ regeneration, or by soaking regeneration plates with $5 \mathrm{ml}$ phage buffer and testing the latter suspension for the presence of phages. We carried out transfection experiments for all the phages isolated, using 5-10 $\mu \mathrm{g}$ DNA and $25 \%$ (w/v) PEG (mol. wt 6000). Using $S$. cattleya or $S$. venezuelae as host strain, transfectants could be obtained with all the phages. The number of infective centres ranged between 1 in $10^{4}$ and 1 in $10^{5}$ protoplasts as estimated by counting the number of plaques on the transfection plates. This number was in good agreement with other transfection experiments described (Krügel et al., 1980; Suarez \& Chater, 1980; Isogai et al., 1980).

\section{$G+C$ content and molecular weight estimations of DNA}

The base composition of DNA was calculated from buoyant density determinations and the results were compared with estimates derived from thermal denaturation experiments. Such comparison was made because values obtained by equilibrium centrifugation may be influenced 


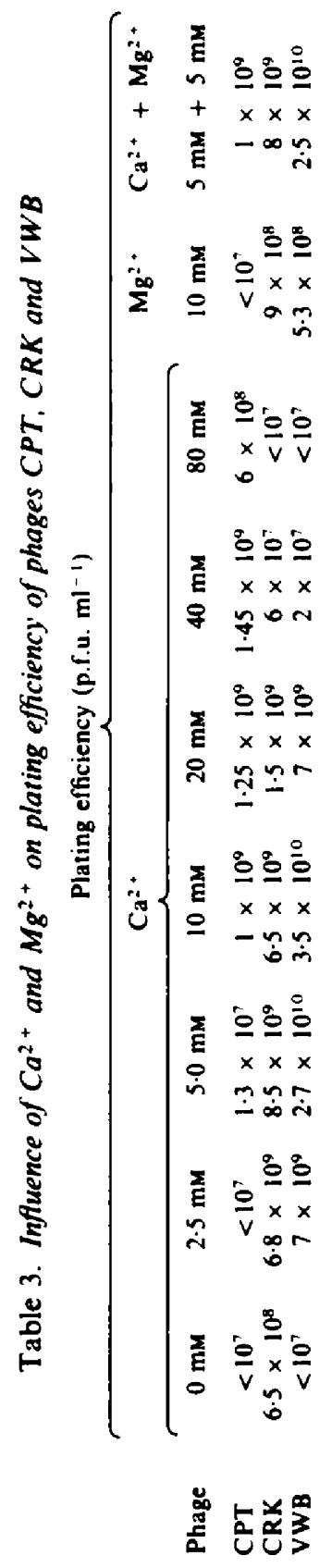


Table 4. Estimation of $G+C$ content of actinophage $D N A$ by melting temperature $\left(T_{m}\right)$ and buoyant density $(\theta)$ determinations

\begin{tabular}{|c|c|c|c|c|}
\hline Phage DNA & $\left({ }^{{ }^{\circ} \mathrm{C}}\right)$ & $\begin{array}{c}\text { Mol \% } \\
\text { G }+\stackrel{\circ}{C} \\
\text { of DNA }\end{array}$ & $\begin{array}{c}\theta \\
\left(\mathrm{g} \mathrm{cm}^{-3}\right)\end{array}$ & $\begin{array}{c}\mathrm{Mol} \% \\
\text { of DNA }+\stackrel{\mathrm{C}}{\mathrm{C}}\end{array}$ \\
\hline $\begin{array}{l}\text { P23 } \\
\text { VP1 (= VW3) } \\
\text { CPC } \\
\text { CRK } \\
\text { CWK } \\
\text { VWB } \\
\text { CT } \\
\text { CPT (= CTK) }\end{array}$ & $\begin{array}{l}72 \cdot 10 \\
71 \cdot 55 \\
71 \cdot 78 \\
76 \cdot 11 \\
82 \cdot 59 \\
83 \cdot 16 \\
83 \cdot 45 \\
85 \cdot 52\end{array}$ & $\begin{array}{l}46 \cdot 2 \\
45 \cdot 1 \\
45 \cdot 6 \\
54 \cdot 6 \\
68 \cdot 1 \\
69 \cdot 3 \\
69.9 \\
74 \cdot 2\end{array}$ & $\begin{array}{l}1.7068 \\
1-7070 \\
1.7053 \\
1.7155 \\
1.7299 \\
1.7304 \\
1.7297 \\
1.7300\end{array}$ & $\begin{array}{l}53 \cdot 2 \\
53 \cdot 5 \\
51 \cdot 8 \\
62 \cdot 1 \\
76 \cdot 7 \\
77 \cdot 2 \\
76 \cdot 4 \\
76 \cdot 2\end{array}$ \\
\hline
\end{tabular}

by glycosylation or methylation of the DNA (Szybalski \& Szybalski, 1977). Consequently, differences between the results obtained from both methods suggest that DNA might be modified.

Except for the temperate phages and for CWK, the $G+C$ content of the phage DNA (Table 4) was quite different from that of streptomycetes, which ranges between 69 and $76 \mathrm{~mol} \%$ (Cross \& Goodfellow, 1973). The base composition of all the virulent phages except CWK ranged between 45 and $54 \mathrm{~mol} \%$ as calculated from $T_{m}$. This $\mathrm{G}+\mathrm{C}$ content was rather low in comparison to other data in the literature (Lomovskaya et al., 1980; Chater, 1980). However, the results were confirmed by both buoyant density and $T_{m}$ determinations. On the other hand, the $\mathrm{G}+\mathrm{C}$ content of the temperate phages was between 70 and $74 \mathrm{~mol} \%$ (on the basis of $T_{m}$ calculations) and these values were in much better agreement with the base composition of streptomycetes.

The lack of full agreement between the base compositions obtained by the two methods might suggest modification of the phage DNA. A further indication of the presence of modified DNA was obtained from restriction enzyme analysis (see below).

The molecular weights of the phage DNAs were estimated by electron microscopic length determination as well as by summation of fragments obtained after digestion with restriction endonucleases (Table 2). CRK and CWK had a relatively small genome; three others, P23, CPC and VP1, had much larger genomes. Results obtained by the two methods were in good agreement for all the phage DNAs except CRK and CT. In these instances restriction enzyme analysis gave remarkably higher genome lengths than obtained by electron microscopic measurements. These differences could be due to the partial digestion of highly modified phage DNA thus giving rise to an overestimation of the genome lengths.

For comparison, the smallest actinophage genome described so far is $36 \mathrm{~kb}$ (Stuttard \& Dwyer, 1981), whereas the largest is $99 \mathrm{~kb}$ (Lomovskaya et al., 1980).

\section{Restriction endonuclease analysis of DNA from different phages}

The DNA of the phages was digested with 23 restriction enzymes (Table 5). A first conclusion which could be drawn was that VPI was identical to VW3, and CPT to CTK, although they were isolated from totally different samples. Furthermore it became apparent that some of the phage DNAs were probably highly modified. For example, the DNA of CPC and VP23 was not cut by $\operatorname{Sau} 3 \mathrm{Al}$, which might imply the methylation of cytidine in this recognition sequence (Huang et al., 1982). The presence of 5-methylcytosine might explain the non-activity of Bam H I or Bg/ll, not only for CPC or VP23, but also in the case of CT and CWK.

The partial or slow digestion of the phage DNA (indicated in Table 5 by + or ?) might suggest that the phages isolated contained methylated or glycosylated DNA, or DNA with unusual base composition, interfering with the binding of the restriction enzymes. These modifications might be caused partially by the host cell machinery, since, after cloning fragments of CPT (ligated to 
Table 5. Restriction enzyme analysis of different phage DNAs

\begin{tabular}{|c|c|c|c|c|c|c|c|c|c|}
\hline \multirow[b]{2}{*}{ Enzyme } & \multirow[b]{2}{*}{ Sequence $†$} & \multicolumn{8}{|c|}{ No. of fragments obtained after digestion of phage DNAł } \\
\hline & & CPC & CRK & CT & $\begin{array}{c}\text { CPT } \\
(=\text { CTK })\end{array}$ & CWK & VWB & $\begin{array}{c}\text { VPI } \\
(=\text { VW } 3)\end{array}$ & VP23 \\
\hline$A / u l$ & $A G \downarrow C \star T$ & D & D & D & D & D & D & D & D \\
\hline BamHI & $\mathrm{G} \downarrow \mathrm{GAT} \star \mathrm{C}^{\circ} \mathrm{C}$ & - & 5 & & 2 & - & $>10$ & - & - \\
\hline$B c / 1$ & $T\rfloor G \star A T C A$ & - & 3 & & 10 & - & $>12$ & 15 & - \\
\hline$B g / I I$ & $A \mid G^{\circ} A T C T$ & - & 7 & & 2 & - & 4 & $>15$ & - \\
\hline BstEII & G\GTNACC & $>12$ & $>12$ & 11 & 16 & 11 & 15 & $>10$ & $>15$ \\
\hline Clal & $\mathrm{AT} \downarrow \mathrm{CG} \star \mathrm{AT}$ & $>15$ & 11 & 6 & 8 & 6 & 2 & $>15$ & $>15$ \\
\hline EcoRI & $G \mid A \star A T T C$ & $+?$ & 8 & $5 ?$ & $4 / 5 ?$ & $6 ?$ & 2 & $>10$ & $>15$ \\
\hline EcoRV & GAT $\ A T C$ & 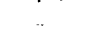 & 8 & 5 & 5 & 5 & 4 & $>15$ & $>15$ \\
\hline HindII & GTPy $\downarrow \mathrm{Pu} \star A^{\circ} \mathrm{C}$ & + & $>12$ & + & $>10$ & $>10$ & $>12$ & + & + \\
\hline Hind III & $\star A 1^{\circ} \mathrm{AG}{ }^{\circ} \mathrm{CTT}$ & - & & & - & - & 3 & 2 & $>15$ \\
\hline Hpal & $G T T \downarrow A \star A^{\circ} C$ & $2 ?$ & 3 & & $2 ?$ & - & - & $8 / 10$ & 8 \\
\hline Hpall & ${ }^{\circ} \mathrm{C} \downarrow \star \mathrm{CGG}$ & D & D & D & $\mathrm{D}$ & D & D & D & D \\
\hline Kpnl & GGTAC $\mid C$ & - & 3 & - & + & - & $>10$ & $6 / 8$ & $>15$ \\
\hline Pstl & CTGCA $\downarrow$ G & & & - & - & + & $>15$ & - & - \\
\hline Sacl & GAGCT $\rfloor C$ & - & & & $>15$ & - & $>15$ & - & - \\
\hline Sall & $\mathrm{G} \downarrow T \star \mathrm{CGAC}$ & - & $6 ?$ & - & $+?$ & - & $>8$ & - & - \\
\hline Sau3Al & $1 \mathbf{G}^{\circ} \mathrm{ATC}$ & - & $\mathrm{D}$ & D & D & D & D & D & - \\
\hline Smal & $\mathrm{CC} \star \mathrm{C} \downarrow \mathrm{GGG}$ & - & & $>10$ & $>15$ & $>10$ & $\geqslant 10$ & - & - \\
\hline SphI & GCATG!C & - & & 8 & 8 & 4 & 10 & - & - \\
\hline SstI & GAGCT\C & & 8 & 12 & $>10$ & 10 & $>15$ & - & - \\
\hline Sstll & CCGCIGG & - & & D & D & D & $>10$ & - & - \\
\hline$X b a I$ & $T\rfloor C T A G \star A$ & 6 & & - & - & - & - & $>15$ & - \\
\hline XhoI & $\mathrm{C} \downarrow \mathrm{T} \star \mathrm{CG} \star \mathrm{AG}$ & - & & 7 & $>12$ & $>10$ & - & - & - \\
\hline
\end{tabular}

† Key: $\star$. Methylation inhibits the enzyme: ${ }^{\circ}$, no inhibition of the enzyme by methylation; $\downarrow$, indication of the point of cleavage.

†D. DNA digested in several small fragments; + , partial digests.

pBR322 or pACYC184) in Escherichia coli HB101, MM294 or in a dam- strain (J. Anné, W. Wohlleben \& A. Pühler, unpublished observations) phage DNA was digested without difficulty by Eco RI, KpnI or Sall : phage DNA isolated from Streptomyces spp. was almost completely resistant to these restriction enzymes.

Modification of phage DNA was, however, probably not caused exclusively by the host, but largely inherent to the DNA itself, provided it was replicating in a host containing the enzymes required for DNA methylation or glycosylation or for delivery of unusual purine or pyrimidine bases. An indication that this assumption was probably correct is the observation that a particular phage, when grown on different Streptomyces spp., yielded DNA with the same pattern of resistance to certain restriction endonucleases, and no new bands appeared in the gels.

The presence of cohesive ends was investigated using digested DNA. The density of the bands in the gels was compared in samples without and with heating and rapid cooling of the digested DNA. Of all the phage DNAs investigated, only VWB showed DNA bands in the gel with variation in intensity (compared to non-heated samples) after heating and rapid cooling. In addition, the sum of the lengths of the smaller fragments which showed increased intensity after heating, as a result of increased amount of non-fused cohesive ends, was equal to the length of the fragments with reduced intensity, i.e. which contained the fused cohesive ends (data not shown). The presence of cohesive ends was also demonstrated by electron microscopy. Circular DNA molecules (20 out of 52 molecules) were observed for VWB (Fig. 3). Circular DNA molecules were not observed for any of the other samples.

The DNA of phage CPT was investigated in more detail, because it was noticed that after complete digestion and subsequent gel electrophoresis two or three bands always stained less intensively. This phenomenon was not caused by partial digestion nor did these bands contain fragments of fused or non-fused sticky ends. Attempts to construct a restriction map revealed that the appearance of the dense bands may have been due to the occurrence of different phage 


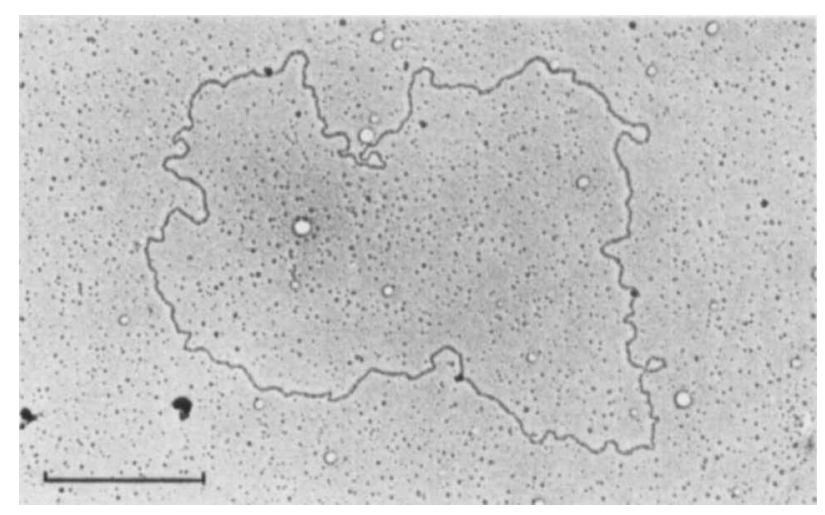

Fig. 3. Electron micrograph of a closed circular phage DNA molecule of $S$. venezuelae phage VWB. The bar marker represents $1 \mu \mathrm{m}$.

lengths present as a result of the DNA packaging mechanism (headful mechanism). This is currently being investigated further.

Finally, when comparing the restriction endonuclease profiles of the different phage genomes, it is remarkable that the phages with the broadest host range contained DNA which was more resistant to endonuclease activity (Table 5). Therefore, for the construction of wide host range phage cloning vehicles, it might be necessary to insert into the phage genome one or more target sites for several commonly used restriction enzymes.

This work was supported by Hoechst AG, Frankfurt, FRG. The authors thank K. Pfleiderer and G. Hauke for technical assistance. J.A. gratefully acknowledges the Belgian Nationaal Fonds voor Wetenschappelijk Onderzoek for financial support, while on leave from the University of Leuven.

\section{REFERENCES}

Bradley, S. R., ANDerson, D. L. \& Jones, L.A (1961). Phylogeny of Actinomycetes as revealed by susceptibility to actinophage. Derelopments in Industrial Microbiology' 2, 223-237.

Burkardt, H. J., Mattes, R., POhler, A. \& HeuMANN, W. (1978). Electron microscopy and computerized evaluation of some partially denatured group P resistance plasmids. Journal of General Microbiology 105, 51-62.

Chater, K. F. (1980). Actinophage DNA. Detelopments in Industrial Microbiology' 21, 65-74.

Chater, K. F., Hopwood, D. A., Kieser, T. \& Thompson, C. J. (1982). Gene cloning in Streptomycetes. Current Topics in Microbiology and Immunology 96, 69-95

Chung, S. T. (1982). Isolation and characterization of Streptomyces fradiae plasmids which are prophage of the actinophage $\phi S F 1$. Gene 17, 239-246.

Cross, T. \& Goodfellow, M. (1973). Taxonomy and classification of the actinomycetes. In Acrinomycetales, Pp. 11-112. Edited by G. Sykes \& F. A. Skinner. London \& New York: Academic Press.

Hirochika, H. \& SAKAgUChi, K. (1982). Analysis of linear plasmids isolated from Sireptomyces: association of protein with the ends of the plasmid DNA. Plasmid 7, 59-65.

Huang, L.-H., Farnet, C. M., Ehrlich, C. \& EHRLICH, M. (1982). Digestion of highly modified bacteriophage DNA by restriction endonucleases. Nucleic Acids Research 10, 1579-1591.

Isogal, T. Takahashi, H. \& Salto, H. (1980). Highfrequency protoplast transfection of Streptomyces partulus 2297 with actinophage R4 DNA. Agricultural and Biological Chemistry 44, 2425-2428.

KORN, F., WeingärtNer, B. \& KutzNer, H. J. (1978). A study of twenty actinophages: morphology, serological relationship and host range. In Genetics of the Actinomycetales, pp. 251-270. Edited by E. Freerksen, I. Tarnok \& J. H. Thumin. Stuttgart \& New York: Fisher G.

KrUGel, H., Fiedler, G. \& Nonck. D. (1980). Transfection of protoplasts from Streptomyces lividans 66 with actinophage SH 10 DNA. Molecular and General Genetics 177, 297-300.

Lomovskaya, N. D., Chater, K. F. \& MKrtumian. N. M. (1980). Genetics and molecular biology of Streptomyces phages. Microbiological Review's 44. 206-229.

Lomovskaya, N. D., Sladkova, I. A., Klochkova, O. A. Chinenova, T. A., Mkrtumian, N. M. \& Orekhov, A. V. (1982). Systems for cloning and transfer in Sireptomyces. In Overproduction of Microbial Products, pp. 395-403. Edited by V. Krumphanzl, B. Sikyta \& Z. Vanek. London \& New York: Academic Press.

MANDEL, M. \& MARMUR, J. (1968). Use of ultraviolet 
absorbance-temperature profile for determining the guanine plus cytosine content of DNA. Methods in Enzymology 12B, 195-206.

MARMUR, J. \& Doty, P. (1962). Determination of base composition of deoxyribonucleic acid from thermal denaturation temperature. Journal of Molecular Biology 5, $109-118$

Miller, J. H. (1972). Experiments in Molecular Genetics. New York: Cold Spring Harbor Laboratory.

Okanishi, M., Suzuki, K. \& Umezawa, H. (1974) Formation and reversion of streptomycete protoplasts: cultural conditions and morphological study Journal of General Microbiology 81, 389400.

Pühler, A.. Burkardt, H. J., Cannon. F. C. \& WoHlleben, W. (1979). Spontaneous degradation of pRDI DNA into unique size classes is recA dependent. Molecular and General Genetics 171. 16.

StutTaRd, C. \& DWYER, M. (1981). A new temperate phage of Streptomices ienezuelue: morphology. DNA molecular-weight, and host range of SV2. Canadian Journal of Microbiology 27, 496499
Slarez, J. E. \& Chater, K. F. (1980). Polyethylene glycol-assisted transfection of Streptomyces protoplasts. Journal of Bacteriology 142, 8-14.

SZYbalsk1, W. \& SzYbalski, E. H. (1977). Equilibrium density gradient centrifugation. In Procedures in Nucleic Acid Research, vol. 2, pp. 311-354. Edited by G. L. Cantoni \& D. R. Davies. New York: Harper \& Row.

Valentine, R. C., Shapizo, B. M. \& Stadtmann, E. R. (1968). Regulation of glutamine synthetase. XII. Electron microscopy of the enzyme from Escherichia coli. Biochemistry 7, 2143 2152.

WOHLleben, W. \& PUHLeR, A. (1982). Isolation and characterization of a plasmid in Streptomyces ghanuensis. In 4 th International Symposium on the Genefics of Industrial Microorganisms. Kyoto, Japan. Abstract Book. p. 122

WOODWARD, R. S. \& Lebowitz, J. (1980). A revised equation relating DNA buoyant density to guanosine plus cy tosine content. Journal of Biochemical and Biophysical Methods 2. 307-309. 